\title{
Pengaruh Musik Klasik Terhadap Hasil dan Aktivitas Belajar Matematika Siswa Kelas VII di SMPN 2 Kota Bengkulu (Studi Ekperimen di SMPN 2 Sawah Lebar Kota Bengkulu)
}

\author{
${ }^{1}$ Yans Al Prakoso, ${ }^{2}$ Dr. Hannifah, M.kom, ${ }^{3}$ Syafdi Maizora,S.Si, M.Pd \\ ${ }^{1,2,3}$ S1 Program Studi Pendidikan Matematika JPMIPA FKIP Utas Bengkulu \\ e-mail : ${ }^{1}$ yansalprakoso@gmail.com, ${ }^{2}$ ifahzen@gmail.com_, ${ }^{3}$ syafdiichiemaizora@gmail.com
}

\begin{abstract}
This research aimed to know The Influence of Classical Music to Activity and Learning Mhatematic Achievement for Student's Grade VII in SMPN 2 Bengkulu City. This is a quasi-experimental research which use pree-test and post-test design. The population in this research is the student's grade VII in SMPN 2 Bengkulu City. There are 276 respondents. The sampling technique that is used is purposive sampling. This research is got 34 respondents for every class. The data analysis that is used is $t$-test. To activity, the result of the study shows that the score of activity with an avarage is in interval $3,4<\bar{X} \leq 4,2$ with criteria is good. And to learning Achievment, the result of the study shows that the score of $t$-end $=0.1012<t$-table $=1.99656$. From the result of study above we can conclude that there is an influence on classical music to ativity for student's grade VII in SMPN 2 Bengkulu City and there is no an influence on classical music to learning mhatematic achievement for student's grade VII in SMPN 2 Bengkulu City.
\end{abstract}

Key words : classical music, activity, and learning mathematic achievement.

\section{PENDAHULUAN}

Sekolah merupakan tempat berkumpulnya peserta didik untuk belajar. Sekolah diharapkan mampu memberikan pengalaman belajar kepada peserta didik untuk menguasai kompetensi yang diperlukan untuk kehidupannya dimasa yang akan datang. Berdasarkan hasil diskusi bersama guru matematika di SMPN 2 Kota Bengkulu, pembelajaran matematika yang dipandang sebagai pelajaran yang membosankan dan sulit membuat peserta didik kurang menyukai untuk belajar matematika. Suasana yang membosankan juga dipandang penyebab utama malas nya perseta didik untuk belajar. Hal tersebut membuat siswa merasa jenuh, bosan, pasif dan siswa hanya menghapal serta mengingat apa yang telah dipelajari. Sedangkan untuk mengingat dan menghapal dalam pembelajaran matematika, dianggap hal yang paling sulit bagi siswa, apalagi matematika juga dipandang sebagai pelajaran yang sangat mengerikan bagi siswa. Hal ini juga menyebabkan siswa kurang termotivasi dalam belajar matematika, sehingga dapat menimbulkan kurangnya pemahaman dari konsep pelajaran yang telah siswa pelajari. Dengan kata lain tujuan pembelajaran matematika yang diharapkan tidak tercapai.

Untuk meningkatan hasil pembelajaran tidak hanya dapat dilakukan dengan jalur keilmuan. Young, pimpinan International Brain Academy (IBA) Indonesia dalam Hasyim (2004) mengatakan bahwa memainkan musik klasik dapat membantu menyeimbangkan otak kiri dan kanan. Anak yang memainkan musik ataupun yang mendengarkan musik akan lebih cerdas secara intelektual dan emosional. Musik sebagai sisi lain yang selama ini dianggap sebagai penghibur belaka diwaktu penat bagi sebagian orang, ternyata mempunyai pengaruh positif guna menciptakan suasana belajar yang kondusif. Melalui metode pencitraannya kepada siswa, mampu memberikan efek yang luar biasa bagi kecerdasan otak terutama pembelajaran.

Otak manusia adalah struktur pusat pengaturan yang memiliki volume sekitar $1.350 \mathrm{cc}$ dan terdiri atas 100 juta saraf sel neutron. Otak adalah organ luar biasa dalam diri manusia. Beratnya hanya sekitar 1,5 kg atau kurang lebih 5\% dari total berat badan tetapi membutuhkan lebih dari 30\% seluruh cadangan kalori yang tersimpan didalam tubuh. (Aldi, 2012). Otak dibagi menjadi 2 yaitu otak kiri dan otak kanan. Otak kiri berkaitan dengan fungsi akademik yang terdiri atas kemampuan berbicara, baca tulis, daya ingat, logika angka dan analisis. Otak kanan sebagai tempat untuk mengembangkan hal-hal yang bersifat artistik, kreatifitas, perasaan, emosi, gaya bahasa, irama musik, imajinasi khayalan, warna, pengenalan diri dan orang lain, serta pengembangan kepribadian. (Muhammad dalam Aldi, 2012).

Taufik Pasiak dalam (Suyadi, 2013:106) menyatakan, pertumbuhan sel-sel baru pada otak berimplikasi pada meningkatnya hasrat untuk menemukan hal-hal baru yang lebih bermakna 
dalam kehidupannya. Inilah sebabnya mengapa meskipun seseorang semakin tua, tetapi otaknya tidak pernah menua. Otak secara naluriah mempunyai ketertarikan terhadap hal-hal baru, dan jika tidak ada maka ia membuat sesuatu yang baru sesuai minatnya. Windura dalam (Aldi, 2012), mengatakan gelombang otak manusia dibedakan menjadi empat tingkatan, yaitu delta, theta, beta, dan alpha. Semuanya dapat diukur dengan alat pendeteksi gelombang otak yang dinamakan EEG (Elektro Enchepolagraph). Tingkatan gelombang tersebut adalah :

1. Delta $(d)$ : keadaan tidur tidak bermimpi (tidur sempurna), frekuensi

$0,5-3 \mathrm{~Hz} /$ detik.

2. Theta $(q)$ : keadaan tidur sedang bermimpi (REM, kreatif), frekuensi

3-8Hz/detik.

3. Alpha (a) : keadaan rileks, berfikir hanya satu hal saja, frekuensi $8-13 \mathrm{~Hz} /$ detik

4. Beta $(b)$ : keadaan waspada, berfikir beberapa hal sekaligus, frekuensi

13-24Hz/detik.

Gelombang otak yang diperlukan dalam belajar adalah gelombang Alpha atau dalam keadaan rileks. Kondisi ini akan membuka jalan menuju kekuatan pikiran bawah sadar dimana tersimpannya memori yang bersifat jangka panjang dan sempurna. (Aldi, 2012). Sedangkan dalam konteks pendidikan, anatomi fungsi otak dapat dibedakan menjadi tiga, yaitu otak besar (cerebrum), otak kecil (cerebellum), dan batang otak (brain stem). Otak besar berhubungan dengan pembelajaran, otak kecil berhubungan dengan proses koordinasi dan keseimbangan, dan batang otak berhubungan dengan pengaturan emosi yang dikendalikan oleh denyut jantung maupun sistem. (Suyadi, 2013:114).

Studi eksperimentasi teknologi pencitraan otak menunjukkan bahwa seni mempunyai struktur paling mendasar dari setiap fungsi otak. Musik, misalnya, mempunyai struktur neurologis pada cortex auditori, dimana bagian otak ini hanya merespon intonasi-intonasi musikal. (Suyadi, 2013:164). Sutriadarma dalam (Aldi, 2012) menyatakan, musik memberikan rangsangan pertumbuhan fungsi-fungsi pada otak (fungsi ingatan, belajar, bahasa, mendengar dan bicara, serta analisis, intelek dan kesadaran) dan merangsang pertumbuhan gudang ingatan. Dengan menikmati musik pusat ingatan anak semakin lama semakin berkembang sehingga daya ingat anak semakin besar sehingga rangsangan proses belajar anak menjadi lebih baik. Musbikin dalam Aldi (2012) mengatakan, para ahli menilai alunan Musik Klasik dapat merangsang pertumbuhan serta meluaskan fungsi otak. Musik Klasik tergolong musik yang memiliki nada yang kalem dan tenang. Inilah yang memicu gelombang di otak yang dapat menenangkan dan dapat merangsang sistem jaringan neutron di otak.

Gunawan dalam Christiani (2004), mengatakan bahwa ada hubungan yang sangat erat antara musik dan matematika. Jika musik terdiri dari ketukan, irama dan nada, maka matematika adalah sebuah angka. Sama hal nya dengan matematika. angka dalah matematika dan matematika adalah angka. Jika musik dapat melatih meningkatkan konsentrasi, melakukan pemikiran yang rumit dan menciptakan ketenangan, maka matematika memerlukan konsentrasi yang penuh untuk memecahkan persoalan yang rumit. Hal ini berarti musik dapat membantu anak meningkatkan konsentrasi dan kondisi tubuh yang lebih baik dalam mengerjakan matematika.

Musik berpengaruh kuat pada lingkungan belajar. Penelitian menunjukkan bahwa belajar lebih mudah dan cepat jika pelajar berada dalam kondisi santai atau represif. Detak jantung orang dalam keadaan seperti ini adalah 60 sampai 80 kali per menit. Kebanyakan musik barok (klasik) sesuai dengan detak jantung manusia yang santai dalam kondisi belajar yang optimal. (Schuster dan Gritton dalam Darmansyah, 2010:37).

Matematika yang dipandang sebagai pembelajaran yang menyeramkan dan sulit terkadang cenderung membuat siswa sedikit malas bahkan enggan untuk belajar matematika. Tambah lagi, dengan adanya sebagian besar murid yang menilai guru dalam pelajaran matematika adalah guru yang sangar, semakin menambah momok dalam pembelajaran matematika. Oleh karena itu, dengan memulai mengkondusifkan suasana belajar dan mengubah mainset siswa tentang matematika dinilai sebagai langkah awal untuk tercapainya hasil belajar siswa yang maksimal, yaitu dengan memberikan suasana yang santai dalam pembelajaran sehingga membuat siswa nyaman dan menepis semua anggapan tentang matematika maupun guru matematika. Dengan kata lain, menggabungkan seni kedalam matematika cenderung dapat menimbulkan suasana yang efektif, menambah semangat belajar siswa dan mampu meningkatkan konsentrasi siswa dalam menyelesaikan masalah-masalah yang rumit dalam matematika, dengan seni adalah Musik 
Darmansyah (2010:35) mengatakan, pembelajaran yang didukung oleh suasana yang kondusif akan memberikan dampak terhadap peningkatan hasil belajar. Suasana itu kebanyakan dipengaruhi berbagai faktor seperti sirkulasi udara dalam ruangan, pencahayaan dan pengaruh musik dalam suasana pembelajaran. Sebagaimana dikatakan Bobbi DePorter,dkk dalam Darmansyah (2010:36) bahwa musik sekurang-kurangnya bermanfaat untuk (1) menata suasana hati, (2) meningkatkan hasil belajar yang diinginkan, (3) menyoroti hal-hal yang penting. Dengan kata lain suasana hati memberikan pengaruh yang berarti terhadap capaian hasil belajar. Perasaan gembira, nyaman dan relaks dapat membuka peluang terutama otak untuk bekerja secara ringan. Dan tentu saja mempermudah untuk mengingat. (Darmansyah, 2010:37).

Menurut Campbell Linda, dkk (2002:149) mengatakan, musik bisa menjadi bagian penting didalam penyusunan pendidikan. Musik memberikan suasana yang ramah ketika siswa memasukinya, menawarkan efek merendahkan setelah melakukan aktifitas fisik, melancarkan peralihan dalam kelas, membangkitkan kembali energi pada hari yang kelabu, dan mengurangi stres yang biasanya menyertai setelah ujian atau tekanan akademik lainya. Hal ini berarti bahwa dengan mengaitkan musik kedalam pembelajaran akan mampu membuat siswa menjadi lebih bersemangat untuk belajar dan mampu merangsang otak untuk bekerja. Diterangkan oleh Campbell Linda, dkk (2002:149) yang juga mengatakan, ketika memutar musik yang lembut menjadi "latar belakang" pada saat siswa memasuki kelas, musik memiliki kemampuan untuk memfokuskan perhatian murid dan meningkatkan level energi fisik. Para murid biasanya memasuki kelas dengan berbagai macam perhatian., perasaan dan keasyikan tersendiri. Musik dapat menciptakan suasana positif yang akan membantu mereka untuk fokus pada pelajaran.

Dilanjutkan Campbell Linda,dkk (2002:150), penting untuk menentukan kapan musik latar belakang yang akan diputar di dalam kelas. Sering kali, lebih efektif ketika para murid memasuki kelas, pada saat membaca dalam hati, pada saat bekerja secara indiviual, pada saat belajar, ujian dan pergantian mata pelajaran. Bila guru ingin berbicara ketika musik sedang diputar, volume harus dipasang pada level yang tidak mengganggu pembicaraan. Dengan kata lain volume suara musik lebih dikecilkan. Oleh karena itu, dalam penelitian yang penulis teliti ini, peneliti akan menerapkan musik klasik ke dalam pembelajaran dengan memutarkan musik klasik selama pelajaran berlangsung. Hal ini berarti dari awal pembelajaran sampai pembelajaran berakhir musik akan diputar mengiringi proses pembelajaran terebut. Ketika guru menjelaskan materi, volume suara dari musik akan dikecilkan sehingga hanya terdengar suara sayup-sayup dari musik tersebut. Sehingga tidak menggangu ataupun memecahkan konsentrasi siswa pada saat guru menjelaskan materi pembelajaran.

Penelitian ini menggunakan metode pendekatan saintifik dalam proses pembelajarannya. Implementasi Kurikulum 2013 dalam pembelajaran dengan pendekatan saintifik adalah proses pembelajaran yang dirancang sedemikian rupa agar peserta didik secara aktif mengonstruk konsep, hukum atau prinsip melalui tahapan-tahapan mengamati (untuk mnegidentifikasi atau menemukan masalah), merumuskan masalah mengajukan atau merumuskan hipotesis, mengumpukan data dengan berbagai teknik, menganalisis data, menarik kesimpulan dan mengomunikasikan konsep, hukum atau prinsip yang "ditemukan". Pendekatan saintifik dimaksudkan untuk memberikan pemahaman kepada peserta didik dalam mengenal, memahami berbagai materi menggunakan pendekatan ilmiah, bahwa informasi bisa berasal dari mana saja, kapan saja, tidak bergantung pada informasi searah dari guru. Oleh karena itu, kondisi pembelajaran yang diharapkan tercipa diarahkan untuk mendorong peserta didik dalam mencari tahu dari berbagai sumber melalui observasi, dan bukan hanya diberi tahu. (Hosnan, 2014:7). Adapun langkah-langkah dalam pembelajaran saintifik adalah sebagai berikut

\section{Mengamati/observing}

adalah "kegiatan studi yang disengaja dan sistematis tentang fenomena sosial dan gejala-gejala psikis dengan jalan pengamatan dan pencatatan". Kegiatan mengamati/observasi dilakukan dengan tujuan untuk: "mengerti ciri-ciri dan luasnya signifikansi dari interrelasinya elemen-elemen/ unsur-unsur tingkah laku manusia pada fenomena sosial serba kompleks dalam pola-pola kultural tertentu". Dalam kegiatan pembelajaran; siswa mengamati objek yang akan dipelajari. Kegiatan belajarnya adalah membaca, mendengar, menyimak, melihat (tanpa atau dengan alat). Kompetensi yang dikembangkan adalah melatih kesungguhan, ketelitian, mencari informasi.

\section{Menanya}

Dalam kegiatan mengamati, guru membuka kesempatan secara luas kepada peserta didik untuk 
bertanya mengenai apa yang sudah dilihat, disimak, atau dibaca. Guru perlu membimbing peserta didik untuk dapat mengajukan pertanyaan. Melalui kegiatan bertanya dikembangkan rasa ingin tahu peserta didik. Pertanyaan tersebut dapat menjadi dasar untuk mencari informasi yang lebih lanjut dan beragam dari sumber yang ditentukan guru sampai yang ditentukan peserta didik, dari sumber tunggal sampai sumber beragam.

3. Pengumpulan data (Experimenting)

Kegiatan "mengumpulkan informasi" merupakan tindak lanjut dari bertanya. Kegiatan ini dilakukan dengan menggali dan mengumpulkan informasi dari berbagai sumber melalui berbagai cara. Untuk itu peserta didik dapat membaca buku yang lebih banyak, memperhatikan fenomena atau objek yang lebih teliti, atau bahkan sampai melakukan eksperimen.

4. Mengasosiasi (Associating)/Menalar

Associating/"mengasosiasi/mengolah

informasi/menalar" dalam kegiatan pembelajaran sebagaimana disampaikan dalam Permendikbud Nomor 81a Tahun 2013 (Hosnan, 2014: 68) adalah memproses informasi yang sudah dikumpulkan, baik terbatas dari kegiatan mengamati dan kegiatan mengumpulkan infromasi. Pengolahan informasi yang dikumpulkan dari yang bersifat menambah keluasan dan kedalaman sampai kepada.

5. Mengomunikasikan

Pada pendekatan saintifik, guru diharapkan memberi kesempatan kepada peserta didik untuk mengomunikasikan apa yang telah mereka pelajari. Pada tahapan ini, diharapkan peserta didik dapat mengomunikasikan hasil pekerjaan yang telah disusun baik secara bersama-sama dalam kelompok dan atau secara individu dari hasil kesimpulan yang telah dibuat bersama. (Hosnan, 2014: 8).

Adapun tujuan penelitian ini adalah untuk mengetahui adakah pengaruh musik klasik terhadap aktivitas belajar matematika siswa kelas VII di SMPN 2 Kota Bengkulu dan untuk mengetahui adakah pengaruh musik klasik terhadap hasil belajar matematika siswa kelas VII di SMPN 2 Kota Bengkulu.

\section{METODE}

Jenis penelitian yang digunakan adalah penelitian kuantitatif dengan metode penelitian eksperimen semu (quasi experimen). Pada penelitian ini menggunakan desain berbentuk pretest-postest group design atau desain kelompok kontrol eksperimen dengan menggunakan dua sampel yang memberikan perlakuan dan tidak memberikan perlakuan.
Tabe 1. pretest-postest group design

\begin{tabular}{|c|c|c|c|}
\hline Group & Pre-test & Treatment & Pos-test \\
\hline Eksperimen & $\mathrm{O}_{1}$ & $\mathrm{X}$ & $\mathrm{O}_{2}$ \\
\hline Kontrol & $\mathrm{O}_{3}$ & - & $\mathrm{O}_{4}$ \\
\hline
\end{tabular}

Menurut Sugiyono (2012:77), quasi experiment adalah penelitian yang mempunyai kelompok kontrol, tetapi tidak dapat berfungsi sepenuhnya untuk mengontrol veriabel-variabel luar yang mempengaruhi pelaksanaan eksperimen. Kegiatan pra penelitian dilakukan dengan memberi pree-test untuk melihat kehomogen pada kedua kelompok tersebut. Adapun pree-test dalam penelitian ini yaitu dengan mengambil nilai sebelumnya yaitu pada materi Aritmatika Sosial. Dari hasil nilai pree-test diperoleh kelas sampel yaitu kelas eksperimen dan kelas kontrol. Teknik pengambilan sampel dalam penelitian ini dengan menggunakan purposive sampling yang menentukan sampel dengan pertimbangan tertentu yaitu menentukan sampel berdasarkan nilai rata-rata siswa yang sama.

Teknik pengumpulan data post-test dilakukan dengan tes. Tes dilakukan sebelum dan sesudah pemberian perlakuan. Tes dibuat dalam bentuk instrumen penelitian. Sebelum tes diujicobakan, instrumen tes harus melewati uji dari para ahli untuk kelayakan instrumen tes. Selanjutnya instrumen tes kemudian diujicobakan terlebih dahulu untuk menguji validitas, reliabilitas dan tingkat kesukaran. Uji validitas menggunakan rumus korelasi point biserial. Adapun rumus uji validitas butir soal yang digunakan adalah sebagai berikut :

$$
r_{p b i s}=\frac{M_{p}-M_{r}}{S_{t}} \sqrt{\frac{p}{q}}
$$

(Arikunto, 2009:79)

Uji reliabilitas menggunakan rumus alpha dengan skor 1 dan 0 . Adapun rumus reliabilitas butir soal yang digunakan adalah sebagai berikut :

$$
r_{11}=\left(\frac{n}{n-1}\right)\left(\frac{S^{2}-\sum p q}{S^{2}}\right)
$$

(Arikunto, 2009:100)

Daya pembeda menggunkan uji daya pembeda. Adapun rumus daya pembeda yang digunakan adalah sebagai berikut :

$$
\mathrm{DB}=\frac{S_{A}-S_{B}}{\frac{1}{2} \text { n.maks }}
$$

(Jihad dan Haris, 2012:189) 
Taraf kesukaran menggunakan uji taraf kesukaran. Adapun rumus taraf kesukaran yang digunakan adalah sebagai berikut :

$$
\mathrm{TK}=\frac{S_{A}+S_{B}}{n . m a k s}
$$

(Jihad dan Haris, 2012:182)

Teknik analisis data dilakukan secara bertahap. Untuk analisis aktivitas belajar siswa, tahap pertama adalah mencari nilai rata-rata aktivitas siswa untuk setiap pertemuan. Nilai rata-rata aktivitas siswa diperoleh dari lembar aktivitas siswa yang diisi oleh pengamat saat pembelajaran berlangsung. Adapun rumus yang digunakan utuk mengihtung rata-rata aktivitas siswa adalah sebagai berikut :

$$
P_{1}=\frac{\sum_{i=1}^{n} \bar{x}_{i}}{n}
$$

(Sudjana, 2005:67)

Tahap selanjutnya pengujian hipotesis dengan mencari nilai rata-rata total nilai aktivitas belajar siswa dari pertemuan pertama hingga akhir. HO ditolak jika hasil aktivitas siswa berada pada interval baik atau sangat baik. Tahap terakhir yakni nilai hasil rata-rata aktivitas siswa dari dua pengamat tersebut diubah menjadi nilai kuantitatif dengan pengelompokkan nilai skala lima seperti yang terlihat pada tabel berikut :

Tabel 2. Kriteria Klasifikasi Penliaian

\begin{tabular}{|c|c|c|}
\hline Rumus & Rerata Skor & Klasifikasi \\
\hline $\bar{X}>\bar{X}_{i}+1,8 \times s b_{i}$ & $\bar{X}>4,2$ & Sangat Baik \\
\hline $\begin{array}{c}\bar{X}_{i}+0,6 \times s b_{i}<\bar{X} \\
\leq \bar{X}_{i}+1,8 \times s b_{i}\end{array}$ & $3,4<\bar{X} \leq 4,2$ & Baik \\
\hline $\begin{array}{c}\bar{X}_{i}-0,6 \times s b_{i}<\bar{X} \\
\leq \bar{X}_{i}+0,6 \times s b_{i}\end{array}$ & $2,6<\bar{X} \leq 3,4$ & Cukup \\
\hline $\begin{array}{l}\bar{X}_{i}-1,8 \times s b_{i}<\bar{X} \\
\leq \bar{X}_{i}-0,6 \times s b_{i}\end{array}$ & $1,8<\bar{X} \leq 2,6$ & Kurang \\
\hline $\bar{X} \leq \bar{X}_{i}-1,8 \times s b_{i}$ & $\bar{X} \leq 1,8$ & $\begin{array}{c}\text { Sangat } \\
\text { Kurang }\end{array}$ \\
\hline
\end{tabular}

Selanjutnya untuk analisis hasil belajar siswa, tahap pertama adalah pengolahan data awal untuk mencari rata-rata, median, modus, simpangan baku, nilai maksimum, dan nilai minimum. Tahap kedua dilakukan pengujian persyaratan analisis yakni uji normalitas dan homogenitas. Uji normalitas dilakukan untuk menguji normalitas sampel penelitian sehingga hasil penelitian dapat digeneralisasikan. Pengujian ini dilakukan dengan uji Chi-kuadrat $\left(\chi^{2}\right)$. Adapun rumus yang digunakan adalah sebagai berikut :

$$
\chi^{2}=\sum_{i=1}^{k} \frac{\left(f_{o}-f_{h}\right)^{2}}{f_{h}}
$$

(Sugiono, $2012: 107$ )

Uji homogenitas dilakukan untuk melihat homogen atau tidaknya sampel dari kelompok penelitian. Pengujian homogenitas diperoleh dari perbandingan kuadrat simpangan baku (varian) terbesar dan terkecil menggunakan uji Fisher. Adapun rumus yang digunakan adalah sebagai berikut :

$$
\mathrm{F}=\frac{\text { Vterbesar }}{\text { Vterkecil }}
$$

(Sugiono, $2012: 140$ )

Tahap ketiga, dilakukan pengujian hipotesis dengan menggunakan pengujian perbedaan dua rata-rata yakni dengan uji-t. Pengujian dilakukan pada taraf signifikasi $\alpha=0,05$. H0 ditolak jika $t_{\text {hitung }} \geq t_{\text {tabel }}$ yaitu terdapat pengaruh musik klasik terhadap hasil belajar matematika siswa kelas VIIdi SMPN 2 Kota Bengkulu. Adapun rumus yang digunakan adalah sebagai berikut :

$$
\begin{gathered}
t=\frac{\bar{x}_{1}-\bar{x}_{2}}{s \sqrt{\frac{1}{n_{2}}+\frac{1}{n_{2}}}} \\
\operatorname{dan}^{2}=\frac{\left(n_{1}-1\right) s_{1}^{2}+\left(n_{2}-1\right) s_{2}^{2}}{n_{1}+n_{2}-2}
\end{gathered}
$$

(Sudjana, 2005:239)

\section{HASIL DAN PEMBAHASAN}

A. Hasil Penelitian

1. Hasil Analisis Data Aktivitas Belajar Siswa

Setelah kelas eksperimen VII D diberi perlakuan pembelajaran dengan Pendekatan Saintifik serta diiringi musik Klasik dan kelas kontrol VII F diberi perlakuan pembelajaran dengan Pendekatan Saintifik tanpa diiringi musik Klasik, kemudian akan dilihat aktivitas belajar siswa yang mendapatkan perlakuan dengan Pendekatan Saintifik dengan diiringi musik klasik. Adapun hasil dari aktivitas ini merupakan hasil aktivitas belajar matematika siswa selama 6 kali pertemuan dengan pengamat yang berbeda. Adapun hasil dari aktivitas belajar siswa kelas VII D oleh pengamat guru pamong dan teman sebaya disajikan seperti tabel berikut berikut :

Tabel 3. Tabel Aktivitas Belajar Siswa

\begin{tabular}{l|l|l}
\hline Pertemuan ke-i & Rata- & Kriteria \\
\hline
\end{tabular}




\begin{tabular}{|c|c|c|}
\hline & rata & \\
\hline 1 & 3,2 & Cukup \\
\hline 2 & 3,4 & Cukup \\
\hline 3 & 3,3 & Cukup \\
\hline 4 & 4,1 & Baik \\
\hline 5 & 4,2 & Baik \\
\hline 6 & 3,9 & Baik \\
\hline
\end{tabular}

Berdasarkan tabel diatas, selanjutnya untuk pengujian hipotesis aktivitas belajar siswa dilakukan dengan mengelompokkan nilai skala lima yang diubah menjadi nilai. Adapun hipotesis yang akan diuji adalah:

$\mathrm{H} 0=$ "Tidak terdapat pengaruh Musik Klasik terhadap aktivitas belajar matematika siswa kelas VII di SMP Negeri 2 Kota Bengkulu."

$\mathrm{H}_{1}=$ "Terdapat pengaruh Musik Klasik terhadap hasil belajar matematika siswa kelas VII di SMP Negeri2 Kota Bengkulu."

Kriteria pengujian jika $\bar{X}>4,2$ dengan kriterian sangat baik atau jika $3,4<\bar{X} \leq 4,2$ dengan kriteria baik, maka berdasarkan kriteria klasifikasi penilaian maka hasil aktivitas belajar siswa meningkat dan $\mathrm{H} 0$ ditolak. Sedangkan dalam kondisi lain yaitu 2,6 $<\bar{X} \leq 3,4$ dengan kriteria cukup, $1,8<\bar{X} \leq 2,6$ dengan kriteria kurang, dan $\bar{X} \leq 1,8$ dengan kriteria sangat kurang, H0 diterima. Dari hasil perhitungan dengan menggunakan rumus rata-rata total, maka diperoleh hasil uji sebagai berikut:

Tabel 4. Hasil Uji Hipotesis Aktivitas Belajar Siswa

\begin{tabular}{|l|l|l|}
\hline $\begin{array}{l}\text { Rata-rata } \\
\text { Total }\end{array}$ & Kriteria & Keterangan \\
\hline 3,68333 & Baik & Ho ditolak \\
\hline
\end{tabular}

Berdasarkan tabel.2, dapat dilihat bahwa nilai berada pada interval $3,4<\bar{X} \leq 4,2$ dengan kreiteria baik, maka $\mathrm{Ho}$ ditolak. Jadi dapat disimpulkan bahwa terdapat pengaruh Musik Klasik terhadap aktivitas belajar matematika siswa kelas VII di SMP Negeri 2 Kota Bengkulu.

\section{Hasil Analisis Data Hasil Belajar Siswa}

Berdasarkan hasil post-test kedua kelas sampel, selanjutnya Uji normalitas data dilakukan dengan uji chi square. adapun hipotesisnya sebagai berikut:

H0 : data berdistribusi normal

$\mathrm{H} 1$ : data tidak berdistribusi normal

Kriteria pengujiannya Jika $X^{2}$ hitung $\leq$ $X^{2}$ tabel maka H0 diterima, dalam kondisi lain H0 ditolak. Dari hasil perhitungan, diperoleh hasil chi square sebagai berikut:

Tabel 5. Hasil Uji Chi-Square

\begin{tabular}{|l|l|l|l|}
\hline Kelas & $X^{2}$ hitung & $X^{2}$ tabel & Keterangan \\
\hline Eksperimen & 9,7199 & 11,070 & Ho diterima \\
\hline Kontrol & 11,003 & 11,070 & Ho diterima \\
\hline
\end{tabular}

Berdasarkan tabel.3 diatas, dapat dilihat bahwa pada kelas eksperimen memiliki $X^{2}$ hitung= $9,7199<X^{2}$ tabel $=11.070$, maka H0 diterima sehingga data berdistribusi normal. Sedangkan pada kelas kontrol memiliki $X^{2}$ hitung $=6.282292$ $<X^{2}$ tabel $=11.070$, maka H0 diterima sehingga data berdistribusi normal.

Selanjutnya uji homogenitas data dilakukan dengan uji Fisher, adapun hipotesisnya sebagai berikut:

$$
\begin{aligned}
& \mathrm{H}_{0}: \sigma^{1} 2=\sigma^{2} 2 \text { (data homogen) } \\
& \mathrm{H}_{1}: \sigma^{1} 2 \neq \sigma^{2} 2 \text { (data tidak homogen) }
\end{aligned}
$$

Kriteria pengujiannya Jika Fhitung $\leq$ Ftabel maka H0 diterima, dalam kondisi lain H0 ditolak. Dari hasil perhitungan, diperoleh hasil uji Fisher sebagai berikut:

Tabel 6. Hasil Uji Fisher

\begin{tabular}{|l|l|l|}
\hline Fhitung & Ftabel & Keterangan \\
\hline 1,0017 & 2,34 & Ho diterima \\
\hline
\end{tabular}

Berdasarkan tabel 6. diatas, dapat dilihat bahwa nilai Fhitung $=1.0017<$ Ftabel $=2.34$, maka $\mathrm{Ho}$ diterima sehingga data homogen. Karena data pada perhitungan berdistribusi normal dan homogen, maka untuk pengujian hipotesis dapat menggunakan uji t.

Untuk pengujian hipotesis hasil belajar siswa dilakukan dengan menggunakan uji t untuk sampel yang independen, karena data homogen dan berdistribusi normal. Adapun hipotesis yang akan diuji adalah:

$\mathrm{H} 0=$ "Tidak terdapat pengaruh Musik Klasik terhadap hasil belajar matematika siswa kelas VII di SMP Negeri 2 Kota Bengkulu."

$\mathrm{H}_{1}=$ "Terdapat pengaruh Musik Klasik terhadap hasil belajar matematika siswa kelas VII di SMP Negeri2 Kota Bengkulu."

Kriteria pengujian jika - ttabel $\leq$ thitung $\leq$ ttabel maka $\mathrm{H} 0$ diterima, dalam kondisi lain $\mathrm{H} 0$ ditolak. Dari hasil perhitungan, diperoleh hasil uji t sebagai berikut:

Tabel 7. Hasil Uji t

\begin{tabular}{|l|l|l|}
\hline Thitung & Ttabel & Keterangan \\
\hline 0,1012 & 1,99656 & Ho diterima \\
\hline
\end{tabular}


Berdasarkan tabel 5. diatas, dapat dilihat bahwa nilai - tabel $=-1.99656<$ thitung $=0.1012<$ ttabel $=1.99656$, maka $\mathrm{H} 0$ diterima. Jadi dapat disimpulan bahwa tidak terdapat pengaruh Musik Klasik terhadap hasil belajar matematika siswa kelas VII di SMP Negeri 2 Kota Bengkulu.

\section{B. Pembahasan}

\section{Aktivitas Belajar Siswa}

Dalam hal ini, akan dilihat perbandingan aktivitas belajar siswa ditinjau dari proses pengerjaan LKS yang diberikan guru kepada siswa antara kelas eksperimen yang menggunakan musik klasik dan kelas kontrol yang tidak menggunakan musik klasik. Pada tahap mengamati, tidak terlalu terlihat perbedaan antara kelas eksperimen dan kelas kontrol dalam proses pengerjaan LKS. Kedua kelas sampel mampu mengikuti intruksi yang diberikan didalam LKS dengan baik dan tenang. Hanya saja pada pertemuan ke-1 dan ke-2, pada proses mengamati kedua kelas masih kebingungan dalam mengerjakan LKS. Hal ini disebabkan siswa belum terbiasa untuk belajar dengan menggunakan LKS.

Selanjutnya tahap menanya. Pada tahap menanya, aktivitas belajar siswa kelas eksperimen jauh berbeda dengan kelas kontrol. Pada kelas eksperimen, siswa antusias untuk bertanya kepada guru tentang hal-hal yang mereka tidak ketahui atau kebingungan yang terdapat didalam LKS. Tak jarang, sesekali siswa sudah mampu untuk berfikir kritis dalam membuat pertanyaan yang telah disediakan pada lembar LKS. Sedangkan pada kelas kontrol, siswa yang antusias untuk bertanya hanya siswa-siswa yang memang termasuk kedalam siswa yang berkemampuan tinggi saja.

Selanjutnya tahap mencoba. Pada tahap mencoba, tidak terlalu kelihatan perbedan aktivitas belajar siswa kelas eksperimen dan kelas kontrol. Kedua kelas mampu mengikuti intruksi yang diberikan didalam LKS. Hanya saja, pada kelas eksperimen, suasana kelas pada tahap menoba lebih terkontrol dibandingkan dengan kelas kontrol. Pada kelas kontrol, masih banyak siswa yang mengobrol dan hanya menumpang nama didalam kelompoknya.

Selanjutnya tahap menalar. Pada tahap menalar, aktivitas belajar siswa kelas eksperimen jauh berbeda dengan kelas kontrol. Hal ini terlihat, hampir seluruh siswa pada kelas kontrol mengerjakan dengan seksama soal yang diberikan didalam LKS. Tak jarang, siswa sesekali bertanya mendekati guru jika mereka kebingungan. Suasana kelas pada kelas eksperimen pun lebih tenang.
Sedangkan pada kelas kontrol, pada tahap menalar hanya 4 sampai 7 kelompok saja yang benar-benar mengerjakan dengan sungguh-sungguh, kebanyakan siswa hanya menunggu jawaban dari teman sekelompoknya saja. Selbihnya, siswa asyik mengobrol dan sesekali terlihat menggangu teman yang lain hanya sekedar untuk bercanda dan bercengkrama.

Selanjutya tahap mengkomunikasikan. Pada tahap mengkomunikasikan, tidak terlalu terlihat perbedaan aktivitas belajar siswa antara kelas eksperimen dan kelas kontrol dalam mengerjakan LKS. Kedua kelas sampel mempu mengerjakan tahap mengkomunikasikan sesuai dengan intruksi didalam LKS. Hanya saja, proses diskusi dalam mengerjakan tahap mengkomunikasikan, kelas eksperimen lebih terlihat antusias dan saling bekerja sama dalam proses pengerjaannya.

Dari penjelasan diatas, dapat disimpulkan bahwa musik berpangaruh kuat terhadap aktivitas belajar siswa. Jika ditinjau dari proses pengerjaan LKS, musik terlihat sangat berpengaruh pada proses menanya dan menalar. Jika ditinjau dari suasana belajar, Baik kelas eksperimen maupun kelas kontrol, proses diskusi berjalan dengan baik namun pada kelas eksperimen suasana belajar yang nyaman dan kondusif membuat diskusi menjadi lebih berjalan dibandingkan dengan kelas kontrol. Hal ini diakibatkan dengan adanya musik, siswa pada kelas eksperimen sudah tidak ada waktu untuk mengobrol atau bercengkrama kepada teman sebaya nya, dikarenakan jika terlalu banyak pendengaran dan suara maka siswa sendiri yang akan terganggu. Sesekali ada siswa yang marah jika temannya yang lain sibuk mengobrol atau memncing keributan. Sesekali siswa marah dengan mengucapkan "marolah pekau". Kata yang sering terlontar dikelas eksperimen ketika proses pembelajaran berlangsung.

\section{Hasil Belajar Siswa}

Berdasarkan hasil uji hipotesis hasil belajar siswa diketahui bahwa tidak terdapat pengaruh Musik Klasik terhadap hasil belajar matematika siswa kelas VII di SMP Negeri 2 Kota Bengkulu. Hal ini dikarenakan karenakan model pembelajaran yang digunakan kedua kelas memiliki langkah yang sama yaitu dengan menggunakan pendekatan Saintifik, namun pada kelas eksperimen pembelajaran berlangsung dengan diiringi musik Klasik. Selain itu, Musik dalam pembelajaran yang jarang ditemukan selama proses pembelajaran berlngsung, membuat siswa belum sepenuhnya bisa beradaptasi dengan pembelajaran yang menggunakan metode tersebut. Namun berdasarkan 
konsep belajar dan pembelajaran bahwa belajar pada prosesnya akan memunculkan perubahan terhadap pola fikir, sikap, maupun tingkah laku. Oleh karena itu akan dilihat perubahan hasil belajar matematika siswa sebagai berikut:

a. Perbedaan kemampuan awal dan hasil belajar siswa pada kelas eksperimen

Berdasarkan hasil kemampuan awal dan posttest dan hasil temuan peneliti dilapangan, akan dilihat perbedaan hasil belajar siswa pada kelas eksperimen yang menerapkan pendekatan ssaintifik dengan diiringi musik klasik berdasarkan tingkat kemampuan awalanya sebagai berikut:

\section{Siswa berkemampuan awal tinggi}

Siswa yang masuk pada kategori berkemampuan awal tinggi adalah siswa yang memiliki rentang nilai awal 70-85 yang berjumlah 10 orang siswa dengan rata-rata nilai awal 73,5 dan rata-rata nilai akhir 82,8 .

Tabel 8. Hasil Belajar Kemampuan Awal Tinggi

\begin{tabular}{|c|l|c|c|}
\hline \multicolumn{4}{|c|}{ Kemampuan Awal Tinggi } \\
\hline $\begin{array}{c}\mathrm{N} \\
\mathrm{o}\end{array}$ & Nama & $\begin{array}{c}\text { Kemampuan } \\
\text { Awal }\end{array}$ & Post-Tes \\
\hline 1 & AIA & 70 & 68 \\
\hline 2 & DLA & 80 & 92 \\
\hline 3 & FMP & 70 & 88 \\
\hline 4 & GHP & 70 & 76 \\
\hline 5 & IM & 80 & 92 \\
\hline 6 & MSA & 80 & 80 \\
\hline 7 & MR & 70 & 76 \\
\hline 8 & NH & 70 & 72 \\
\hline 9 & RB & 70 & 88 \\
\hline 10 & SA & 75 & 96 \\
\hline Rata-rata & 73,5 & 83,8 \\
\hline
\end{tabular}

Berdasarkan tabel diatas, dapat dilihat bahwa terjadi peningkatan hasil belajar siswa untuk kelompok nilai siswa berkemampuan awal tinggi.

\section{Siswa berkemampuan awal sedang}

Siswa yang masuk pada kategori berkemampuan awal sedang adalah siswa yang memiliki rentang nilai awal 50-69 yang berjumlah 15 orang siswa dengan rata-rata nilai awal 61,33 dan rata-rata nilai akhir 73,33.

Tabel 9. Hasil Belajar Kemampuan Awal Sedang

\begin{tabular}{|c|l|c|c|}
\hline \multicolumn{4}{|c|}{ Kemampuan Awal Sedang } \\
\hline No & Nama & Kemampuan Awal & Post-Tes \\
\hline 1 & AAS & 60 & 72 \\
\hline 2 & ACP & 65 & 84 \\
\hline 3 & AJH & 60 & 68 \\
\hline 4 & ARSP & 65 & 76 \\
\hline 5 & DS & 65 & 76 \\
\hline
\end{tabular}

\begin{tabular}{|c|l|c|c|}
\hline 6 & DH & 65 & 80 \\
\hline 7 & DKI & 60 & 76 \\
\hline 8 & JNH & 50 & 68 \\
\hline 9 & LR & 55 & 52 \\
\hline 10 & MAN & 65 & 64 \\
\hline 11 & SY & 65 & 76 \\
\hline 12 & SD & 60 & 68 \\
\hline 14 & ZA & 60 & 88 \\
\hline 15 & ZSM & 65 & 80 \\
\hline \multicolumn{2}{|l|}{ Rata-rata } & 61,33 & 73,33 \\
\hline
\end{tabular}

Berdasarkan tabel diatas, dapat dilihat bahwa terjadi peningkatan hasil belajar siswa untuk kelompok nilai siswa berkemampuan awal sedang.

\section{Siswa berkemampuan awal rendah}

Siswa yang masuk pada kategori berkemampuan awal rendah adalah siswa yang memiliki rentang nilai awal 10-49 yang berjumlah 9 orang siswa dengan rata-rata nilai awal 38,33 dan rata-rata nilai akhir 51,556.

Tabel .10 Hasil Belajar Kemampuan Awal Rendah

\begin{tabular}{|c|l|c|c|}
\hline \multicolumn{4}{|c|}{ Kemampuan Awal Rendah } \\
\hline No & Nama & $\begin{array}{c}\text { Kemampuan } \\
\text { Awal }\end{array}$ & Post-Tes \\
\hline 1 & ATP & 10 & 32 \\
\hline 2 & DPP & 40 & 64 \\
\hline 3 & FZ & 35 & 48 \\
\hline 4 & FRI & 40 & 52 \\
\hline 5 & FM & 45 & 48 \\
\hline 6 & KRA & 45 & 44 \\
\hline 7 & MI & 40 & 48 \\
\hline 8 & PG & 45 & 68 \\
\hline 9 & ZP & 45 & 60 \\
\hline Rata-rata & 38,33 & 51,556 \\
\hline
\end{tabular}

Berdasarkan tabel diatas, dapat dilihat bahwa terjadi peningkatan hasil belajar siswa untuk kelompok nilai siswa berkemampuan awal rendah.

b. Perbedaan kemampuan awal dan hasil belajar siswa pada kelas kontrol

Berdasarkan hasil kemampuan awal dan post test, akan dilihat perbedaan hasil belajar siswa pada kelas eksperimen yang menerapkan pendekatan ssaintifik dengan diiringi musik klasik berdasarkan tingkat kemampuan awalanya sebagai berikut:

\section{Siswa berkemampuan awal tinggi}

Siswa yang masuk pada kategori berkemampuan awal tinggi adalah siswa yang memiliki rentang nilai awal 70-85 yang berjumlah 14 orang siswa dengan rata-rata nilai awal 75,35 dan rata-rata nilai akhir 79,48.

\section{Siswa berkemampuan awal sedang}


Siswa yang masuk pada kategori berkemampuan awal sedang adalah siswa yang memiliki rentang nilai awal 50-69 yang berjumlah 11 orang siswa dengan rata-rata nilai awal 59,09 dan rata-rata nilai akhir 63,63.

\section{Siswa berkemampuan awal rendah}

Siswa yang masuk pada kategori berkemampuan awal rendah adalah siswa yang memiliki rentang nilai awal 10-49 yang berjumlah 9 orang siswa dengan rata-rata nilai awal 37,778 dan rata-rata nilai akhir 45,33.

\section{PENUTUP}

\section{A. Simpulan}

Berdasarkan hasil penelitian yang telah dilakukan, maka dapat ditarik dua kesimpulan, yaitu :

1. Terdapat pengaruh yang signifikan Musik Klasik terhadap aktivitas belajar siswa matematika kelas VII di SMP Negeri 2 Kota Bengkulu. Hal ini ditunjukkan dari hasil uji hipotesis diperoleh bahwa nilai aktivitas siswa berada pada kriteria baik, sehingga $\mathrm{Ho}$ ditolak.

2. Tidak terdapat pengaruh yang signifikan Musik Klasik terhadap hasil belajar siswa matematika kelas VII di SMP Negeri 2 Kota Bengkulu. Hal ini ditunjukkan dari hasil uji $\mathrm{t}$ diperoleh bahwa nilai -ttabel $=-1.99656<$ tthitung $=0.1012$ $<$ ttabel $=1.99656$, maka Ho diterima.

\section{B. Saran}

Saran yang dapat dikemukakan berdasarkan hasil penelitian yang telah dilaksanakan adalah:

1. Bagi para guru, penerapan musik klasik dalam pembelajaran dapat meningkatkan aktivitas belajar siswa serta dapat meningkatkan hasil belajar siswa, namun dengan mempertimbangkan hal-hal sebagai berikut :

a. Saat guru menjelaskan hendaknya menggunakan musik klasik dengan nada slow. Musik klasik dengan nada slow yaitu, musik klasik yang mengandung irama ketenangan dengan tempo yang lambat datar. Hal ini bertujuan agar siswa dapat menyimak penjelasan yang diberikan guru dengan baik.

b. Saat berdiskusi hendaknya menggunakan musik klasik dengan nada melow (kencang atau bersemangat). Musik klasik dengan nada melow (kencang atau semangat) adalah musik klasik yang mengandung nada mendayu dan bersemangat serta mempunyai tempo yang datar, turun, dan tinggi. Hal ini bertujuan agar siswa bersemangat sehingga

siswa tidak mengantuk saat proses pembelajaran berlangsung.

c. Sebaiknya jenis musik klasik yang digunakan mengandung alat musik seperti piano, biola, dan seruling.

2. Sebaiknya jika ingin menerapkan musik klasik dalam pembelajaran hendaknya guru dapat memperhatikan sarana dan prasarana sebagai berikut :

a. Pastikan kelas memiliki aliran listrik yang baik

b. Gunakan speaker yang dapat didengar dengan jangkauan minimal 5 meter.

c. Pastikan menggunakan musik klasik dengan komposer yang memang benar dibidang musik klasik itu sendiri. Seperti Yiruma dan Kitaro, karena dengan memilih musik klasik yang baik maka akan mempengaruhi lingkungan belajar dan lingkungan belajar akan mempengaruhi aktivitas dan hasil belajar.

\section{DAFTAR PUSTAKA}

Aldi. 2012. Pengaruh Belajar Musik Klasik
Terhadap Peningkatan Prestasi
Belajar Pada Anak SD Di Studio
Musik Surakarta.

Arikunto, Suharsimi. 2009. Dasar-Dasar Evaluasi Pendidikan. Jakarta: Bumi Aksara

Chambel, Linda, dkk. 2002. Multiple Inteligences, Metode Terbaru Melesatkan Kecerdasan. Depok: Insiasi Pers.

Christianti, Martha. 2004. Pengaruh Musik Instrumental Terhadap Hasil Belajar Matematika Siswa Kelas 1 Sekolah Dasar.

Darmansyah. 2010. Strategi Pembelajaran Menyenangkan Dengan Humor. Jakarta: Bumi Askara.

Hasim AS, M. 2004. Pengaruh Musik Klasik Terhadap Hasil Belajar Matematika.

Hosnan. 2014. Pendekatan Saintifik dan Kontekstual dalam Pembelajaran. Yogyakarta: Pustaka Belajar.

Jihad dan Haris. 2013. Evaluasi Pembelajaran. Yogyakarta: Pustaka Belajar.

Sanjaya, Wina. 2006. Strategi Pembelajaran Berorientasi Standar Proses Pendidikan. Jakarta: Kencana Prenada Media.

Sujana. 1995. Metode Statistika Edisi Ke-6. Bandung: Tarsito. 
Sugiono. 2012. Metode Penelitian Kuantitatif,

Kualitatif, dan R\&D. Bandung:

Alfabeta.

Sugiono. 2012. Statistika Untuk Penelitian. Bandung: Alfabeta. 